\title{
Development and regeneration of somatic embryos from leaves-derived calli of Coffea liberica
}

\author{
FITRIA ARDIYANI ${ }^{2}$, EDY SETITI WIDA UTAMI ${ }^{1, \bullet}$, HERY PURNOBASUKI $^{1}$, SENJA APRILIA PARAMITA $^{3}$ \\ ${ }^{1}$ Department of Biology, Faculty of Science and Technology, Universitas Airlangga. Jl. Mulyorejo, Surabaya 60115, East Java, Indonesia. \\ Tel. $\{$ +62-31-5936501, Fax.: +62-31-5936502 •email: edy-s-w-u@ fst.unair.ac.id \\ ${ }^{2}$ Indonesian Coffee and Cocoa Research Institute. J1. PB Sudirman 90, Jember 68118, East Java, Indonesia \\ ${ }^{3}$ Biology Graduate Program, Faculty of Science and Technology, Universitas Airlangga. Jl. Mulyorejo, Surabaya 60115, East Java, Indonesia
}

Manuscript received: 16 October 2020. Revision accepted: 27 November 2020.

\begin{abstract}
Ardiyani F, Utami ESW, Purnobasuki H, Paramita SA. 2020. Development and regeneration of somatic embryos from leavesderived calli of Coffea liberica. Biodiversitas 21: 5829-5834. Coffea liberica is an important and potentially commercial plant with a high economic value from the Coffea genus. Therefore, the availability of planting material is needed to increase productivity and ensure the sustainability of its farming. Somatic embryogenesis is a powerful propagation method used to produce clonal plants from limited genetic material. In the present research, we have shown that Coffea liberica could be successfully regenerated in vitro via somatic embryogenesis from leaves derived embryogenic callus. These calli were cultured on Murashige Skoog (MS) medium added with $1 \mathrm{mgL}^{-1} \mathrm{BAP}$ or in combination with $2.4 \mathrm{D}\left(0.5,1.0,1.5\right.$ and $\left.2 \mathrm{mgL}^{-1}\right)$ for embryo development induction. Furthermore, the medium containing only BAP was best for embryo development induction after culturing for 12 weeks, with the highest number of cotyledonary stage embryos (17.8\%) and producing a total of embryo (20.2). Following cotyledonary stage embryo were cultured on new MS medium containing $0.5 \mathrm{mgL}^{-1} \mathrm{BAP}^{-0.5}$ $\mathrm{mgL}^{-1} \mathrm{IAA}, 0.5 \mathrm{mgL}^{-1} \mathrm{NAA}$ only, and $0.5 \mathrm{mgL}^{-1} \mathrm{BAP}$ in combination with $0.5 \mathrm{mgL}^{-1} \mathrm{IAA}$ or $0.5 \mathrm{mgL}^{-1} \mathrm{NAA}$. Interestingly, the results showed that cotyledonary stage embryos were converted into complete plants at all treatment, but the MS medium containing $0.5 \mathrm{mgL}^{-1}$ $\mathrm{BAP}$ was found to be the most effective in promoting regeneration with 2.6 leaves per-plantlet and height of $5.2 \mathrm{~mm}$. Based morphological analysis confirm that the development of somatic embryo from leaves-derived calli of $C$. liberica started with the formation of embryo globular, heart, torpedo, cotyledonary stages, and finally conversion of cotyledonary embryo into complete plant.
\end{abstract}

Keywords: Coffea liberica, plant growth regulators, regeneration, somatic embryo

\section{INTRODUCTION}

Coffea liberica belongs to the family Rubiaceae, and it is one of the important commodities in the global market besides Coffea canephora, Coffea arabica, and Coffea excelsa. Initially, C. liberica was largely distributed in Africa, from Ivory Coast to the east of Uganda, and from north and south of Cameroon to Angola (Davis et al. 2006). This commodity has many advantages, which include tolerance to drought and high salinity, as well as has the ability to thrive in peat soil (N'Diaye et al. 2005). The Indonesian center of agricultural land research and development, as well as the soil research Institute in 2011 estimated that there were 14.9 million hectares of peat land in Indonesia. This land area spreads across the island of Sumatra 6.4 million hectares (43\%), Kalimantan 4.8 million (32\%), and Papua 3.7 million (25\%), hence a great potential to cultivate in large areas in the future. Certainly, this will require large amounts of planting material.

Coffee can be reproduced generatively with seeds and vegetatively. One embryo seed will produce only one plant, therefore the supply plant is limited. Furthermore, the seedlings produced through seeds have non-uniform characteristics and are not the same as their parent (Aga and Khillare, 2017). Plants produced by conventional vegetative propagation, such as cutting are genetically stable, but are very slow and limited in producing large numbers and require a lot of labor (Etienne et al. 2002).

One of plant propagation methods is through embryo regeneration via somatic cells that can grow into bipolar plants possessing the same characteristics as their parents without gamete fusion (Jimenez et al., 2001). Besides aiming to produce superior seeds in bulk, this technique also aims to improve plant quality. In fact, it can produce large numbers of true-to-type plant seedlings in a short time (Etienne et al. 2006). In addition, somatic embryogenesis can be used in germplasm or endangered genotype conservations (Yang and Zhang, 2010).

Somatic embryogenesis is a powerful tool that is widely used in coffee for biotechnological applications, including propagation and genetic transformation (Etienne et al. 2018). Furthermore, Giridhar et al. (2004) and Herrera et al. (2008) reported successful regeneration of plantletforming embryos through somatic embryogenesis in $C$. canephora. In fact, different authors have recognized their success in inducing and regenerating embryos in $C$. arabica (Gatica-Arias et al. 2008 and Kahia et al. 2016). In addition, Ardiyani (2015) reported embryogenic callus induction in $C$. liberica, but it failed to develop into somatic embryos.

Some factors such as the type of explant, nutrient, and growing environmental conditions affect the success of the somatic embryogenesis (Campos et al. 2017; Nic-Can et al. 
2015). Meanwhile, according to Mira et al. (2016) and Jimenez (2005), another crucial factor that influences somatic embryogenesis is the plant growth regulators. Each stage of the development in vitro process is influenced by the presence of growth regulators in the media (Vondráková et al. 2016).

Plant growth regulators often used in somatic embryogenesis are the auxin and cytokinin groups. Auxin plays an important role in the induction of embryogenic callus and initiation of somatic embryo formation (Chithra et al. 2005; Arnold et al. 2002), while cytokinins play a role in stimulating somatic embryo growth and development (Pádua et al. 2018). The combination of growth regulators that are appropriate for both type and concentration is specific for each type of plant (Santana-Buzzy et al. 2007). Therefore, this study aimed to evaluate the effects of plant growth regulators on induction and development of somatic embryos C. liberica.

\section{MATERIALS AND METHODS}

\section{Preparation of embryogenic callus as a source of explants}

Young leaves of C. liberica were sterilized using a $30 \%$ sodium hypochlorite solution and $70 \%$ alcohol. The leaves were then cut to a size of $\pm 0.5 \mathrm{~cm} \times 0.5 \mathrm{~cm}^{2}$ and cultured on Murashige and Skoog (Murashige and Skoog, 1962) medium added with $1 \mathrm{mgL}^{-1} 2.4$ dichlorophenoxyacetic acid (2.4 D) (Merck, Made in Germany). Also, it was added with $30 \mathrm{gL}^{-1}$ sucrose (Merck, Made in Germany), and solidified with $4 \mathrm{gL}^{-1}$ gelling agents (Gelrite-Gelzan). The cultures were incubated for 8 weeks, then embryonic calli ( Figure 1) (Ardiyani, 2015) were used as the explant in the induction and development of somatic embryo $C$. liberica.

\section{Induction and development of somatic embryos from embryogenic callus}

To evaluate the effect of plant growth regulator on development of somatic embryos, the embryogenic calli were cultured on Murashige and Skoog's medium supplemented with only $1 \mathrm{mgL}^{-1}$ Benzyl Amino Purine (BAP) (Sigma Chemical Co., St. Louis, MO) or in combination with $0.5,1.0,1.5$, and $2.0 \mathrm{mgL}^{-1} 2.4 \mathrm{D}$ (Merck, Made in Germany). Furthermore, all the media were supplemented with $30 \mathrm{~g} / \mathrm{L}$ sucrose (Merck, Made in Germany), solidified with $3 \mathrm{gL}^{-1}$ gelling agents (GelriteGelzan), and set into $\mathrm{pH} 5.7$ before being sterilized at $121^{\circ} \mathrm{C}$ for $15 \mathrm{mins}$. For each treatment, about $10 \mathrm{mg}$ calli were cultured in ten Petri dishes (50 $\mathrm{mm}$ in diameter) that contained $10 \mathrm{~mL}$ of the medium. Also, the cultures were maintained under $16 / 8 \mathrm{~h}$ day/night at $23 \pm 2^{\circ} \mathrm{C}$. After 6,8 , 10 , and 12 weeks of inoculation, the number of somatic embryos in different development stages was calculated using a binocular microscope, Nikon SMZ-1, Japan to define the role of plant growth regulator BAP and 2.4 D on the induction and development of somatic embryos. The processes of the development were classified into four stages according to Dicotyledoneae patterns (Ibrahim et al.
2015), which are: globular stage: the embryos grow round; heart stage: having a heart shape; torpedo stage: the topend of the embryos start forming small cavities and have elongation; and the cotyledon stage: embryos growing longer and visible have cotyledons. In addition, at the end of the 12 weeks after culture, the percentage of somatic embryos in different developmental stages was calculated by dividing the number of embryo in each stage by the total number of embryos x 100.

\section{Regeneration of somatic embryos}

After 12 weeks of culture, the somatic embryos of the cotyledon stage obtained from the induction were used for induction regeneration. Particular embryos of cotyledon stage characterized by $\pm 2 \mathrm{~mm}$ in length were cultured individually on MS medium containing $0.5 \mathrm{mgL}^{-1} \mathrm{BAP}$, $0.5 \mathrm{mgL}^{-1}$ Indole acetic acid. (IAA), $0.5 \mathrm{mgL}^{-1} \mathrm{Naphthalene}^{-1}$ acetic acid (NAA) alone, and $0.5 \mathrm{mgL}^{-1} \mathrm{BAP}$ in combination with $0.5 \mathrm{mgL}^{-1}$ IAA or $0.5 \mathrm{mgL}^{-1} \mathrm{NAA}$. Each treatment has ten replicates, and all the cultures were maintained at $23 \pm 2^{\circ} \mathrm{C}$ under $8 / 16 \mathrm{~h}$ day/night photoperiod. After 12 weeks, the number of root, number of leaves pershoot, and plantlet height were recorded.

\section{Experimental design and data analysis}

All the experiments were laid out in a completely randomized design (CRD). Furthermore, the data were statistically analyzed using analysis of variance (ANOVA). The mean values were separated using Duncan's multiple range test (DMRT) with level of significance at $\mathrm{P}<0.05$ (Duncan 1955). In addition, the statistical package SPSS (Version 21) was used for analysis.

\section{RESULTS AND DISCUSSION}

\section{Induction of embryogenic calli development}

The development of $C$. liberica embryogenic calli was shown in (Figures 1.A-1.G). Meanwhile, the embryonic callus of $C$. liberica used as explants sources in this experiment had light yellow color and granular in texture (Figure 1.A). Initially, the somatic embryogenesis started with the formation of globular embryos on the surface of calli about 6 weeks after culture (WAC) (Figure 1.B). The embryos in this stage were round in shape and white in color. Furthermore, globular embryos would develop into heart stage (Figure 1.C) with suspensor-like structure (sls) that connects it to the media and clear notch (not) within 8 WAC. At $10 \mathrm{WAC}$, the heart stage embryos developed into elongated shapes and become torpedo stage (Figure 1.D). In the $12 \mathrm{WAC}$, the torpedo stage embryo became elongated and transformed into cotyledonary stage having two cotyledons and notch (Figure 1.E). Somatic embryos of C. liberica can regenerate into plantlets through in vitro culture techniques, however, sometimes differences in embryogenesis stages are found (Figure 1.F). This showed that the somatic embryo development process is asynchronous. Similar results have been found in Hibiscus sabdariffa (Konar et al. 2018), Akebia trifoliata (Zou et al. 2019), Helianthus annuus L. (Fu et al. 2017), and 
Capsicum baccatum (Venkataiah et al. 2016). Finally, when the cotyledonary stage embryos were sub-cultured in MS medium containing $1 \mathrm{mgL}^{-1} \mathrm{BAP}$ at $12 \mathrm{WAC}$, they were converted into complete plantlets (Figure 1.G).

\section{Somatic embryo development in varied media} containing varying concentrations and type of plant growth regulators.

After 6, 8, 10, and 12 culture weeks (Figure 2), globular stage somatic embryos were formed at the $6^{\text {th }}$ week in all treatments. Meanwhile, at the $8^{\text {th }}$ week, it was noted that heart stage embryos were formed only added with $1 \mathrm{mgL}^{-1}$ BAP. Furthermore, the formation of embryos in the torpedo and cotyledonary stages was only on the added with a single plant growth regulator, namely $1 \mathrm{mgL}^{-1} \mathrm{BAP}$ at the $10^{\text {th }}$ week. Formation of somatic embryos at various stages (globular, heart, torpedo, and cotyledon) was seen at the $12^{\text {th }}$ week after culture in all treatments. This indicated that added with a single BAP or combined with $2.4 \mathrm{D}$ with various concentration variations gave a positive response to development, such as accelerating the embryo development. This is in accordance with Verma et al. (2018), that embryogenic calli can develop into somatic embryos on media containing a single cytokinin or added with auxins. In fact, Vondrakova et al. (2011) stated that the embryogenic calli Abies alba Mill cultured on media without auxin were able to develop into somatic embryos.

Based on the total embryos formed in various treatments at the $12^{\text {th }}$ week (Table 1.), the highest of total embryos (20.2) were found at $1 \mathrm{mgL}^{-1} \mathrm{BAP}$, followed by $(13.4 ; 11.0 ; 8.9$; and 7.7$)$ in the $1 \mathrm{mgL}^{-1} \mathrm{BAP}+0.5 \mathrm{mgL}^{-1}$ $2.4 \mathrm{D} ; 1 \mathrm{mgL}^{-1} \mathrm{BAP}+1.0 \mathrm{mgL}^{-1} 2.4 \mathrm{D} ; 1 \mathrm{mgL}^{-1} \mathrm{BAP}+1.5$ $\mathrm{mgL}^{-1} 2.4 \mathrm{D}$; and $1 \mathrm{mgL}^{-1} \mathrm{BAP}+2.0 \mathrm{mgL}^{-1} 2.4 \mathrm{D}$. Furthermore, the added with a single BAP growth regulator and its combination with $2.4 \mathrm{D}$ affected the percentage of somatic embryos formed at each stage of development (Table 1).
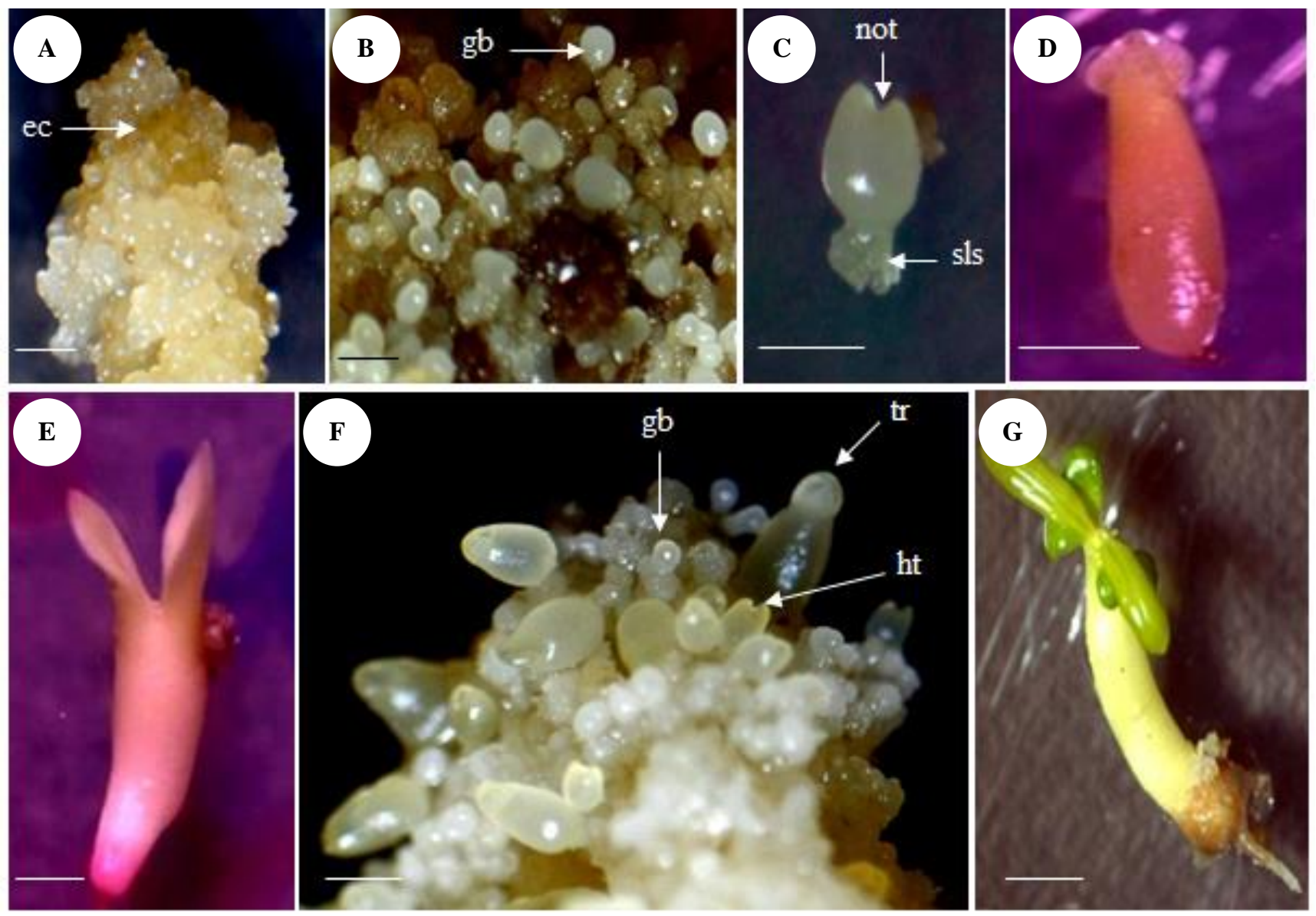

Figure 1. Pattern of somatic embryo development and regeneration in Coffea liberica. A. Light yellow granular embryogenic (ec) calli were used as the explant; B. Formation of globular (gb) embryo which appeared on the surface of calli 6 WAC; C. Heart stage somatic embryo with a clear notch (not) and suspensor like structure (sls) 8 WAC; D. Torpedo stage somatic embryo was formed 10 WAC; E. Final development at cotyledonary stage embryo with distinct cotyledons 12 WAC in MS medium added with $0.5 \mathrm{mgL}^{-1} \mathrm{BAP}$ F. Asynchronous somatic embryo development i.e globular (gb), heart (ht), and torpedo (tr) stage on 12 WAC; G. Formation of plantlets from cotyledonary stage embryos $12 \mathrm{WAC}$ in MS medium added with $1 \mathrm{mgL}^{-1}$ BAP. Scale bars: A. $20 \mathrm{~mm}, \mathrm{~B} .1 \mathrm{~mm}, \mathrm{C} .500 \mu \mathrm{m}, \mathrm{D}$. $375 \mu \mathrm{m}$, E. $200 \mu \mathrm{m}$, F. $1.1 \mathrm{~mm}, \mathrm{G} .1 \mathrm{~mm}$ 
Also, the highest percentage of cotyledonary-stage somatic embryos $(17.8 \%)$ was found in the $1 \mathrm{mgL}^{-1} \mathrm{BAP}$, followed by $(14.7 \% ; 13.2 \% ; 9.4 \%$ and $7.2 \%)$ recorded at the $1 \mathrm{mgL}^{-1} \mathrm{BAP}+0.5 \mathrm{mgL}^{-1} 2.4 \mathrm{D} ; 1 \mathrm{mgL}^{-1} \mathrm{BAP}+2.0$ $\mathrm{mgL}^{-1} 2.4 \mathrm{D} ; 1 \mathrm{mgL}^{-1} \mathrm{BAP}+1.5 \mathrm{mgL}^{-1} 2.4 \mathrm{D}$; and $1 \mathrm{mgL}^{-1}$ $\mathrm{BAP}+1.0 \mathrm{mgL}^{-1} 2.4 \mathrm{D}$. This showed that the added with a single growth regulator BAP provided a better response to embryo development. This is supported by Arnold et al.
(2002), that a way to stimulate development of somatic embryos is by added with cytokinins and reducing or eliminating auxin use. In this research, single cytokinins stimulated the somatic embryo maturation to the cotyledonary stage with the highest percentage. This is in accordance with Verma et al. (2018) that embryogenic calli can develop into somatic embryos when the media containing cytokinins without auxins.
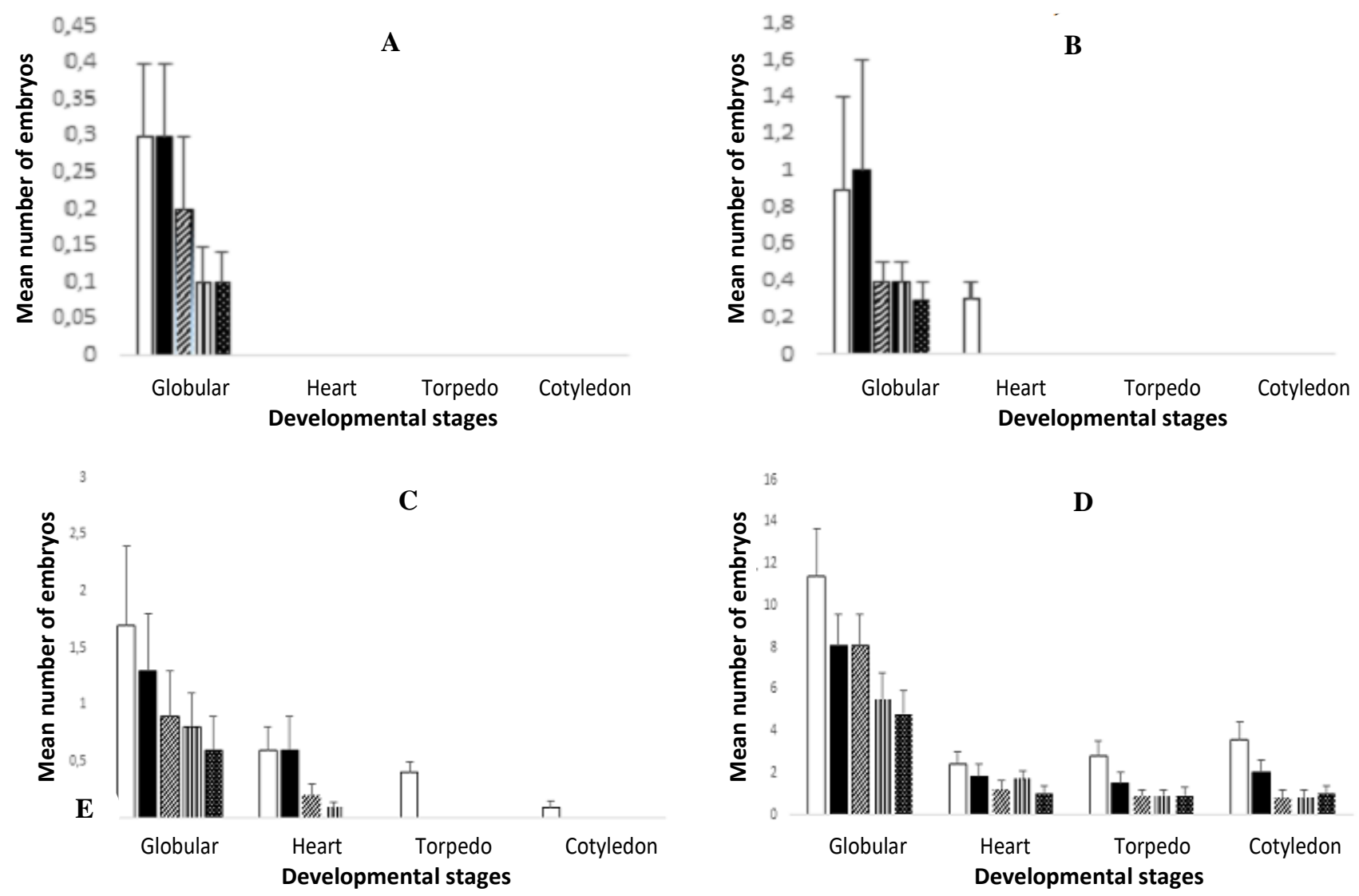

Figure 2. The effect of plant growth regulator on somatic embryos development of $C$. liberica at A. 6, B. 8, C. 10, and D. 12 weeks after in vitro culture. $\square: 1 \mathrm{mgL}^{-1} \mathrm{BAP}+0 \mathrm{mgL}^{-1} 2.4 \mathrm{D} ; \mathbf{\square}: 1 \mathrm{mgL}^{-1} \mathrm{BAP}+0,5 \mathrm{mgL}^{-1} 2.4 \mathrm{D} ; \mathbf{\square}: 1 \mathrm{mgL}^{-1} \mathrm{BAP}+1 \mathrm{mgL}^{-1} 2.4 \mathrm{D}$; $1 \mathrm{mgL}^{-1} \mathrm{BAP}+1,5 \mathrm{mgL}^{-1} 2.4 \mathrm{D}$ and $\boldsymbol{\square}: 1 \mathrm{mgL}^{-1} \mathrm{BAP}+2 \mathrm{mgL}^{-1} 2.4 \mathrm{D} . \mathrm{A}=6 \mathrm{WAC} ; \mathrm{B}=8 \mathrm{WAC} ; \mathrm{C}=10 \mathrm{WAC} ; \mathrm{D}=12 \mathrm{WAC}$.

Table 1. The effect of BAP only or in combination with 2.4 D at various concentrations on somatic embryo development of $C$. liberica for 12 culture weeks.

\begin{tabular}{|c|c|c|c|c|c|c|}
\hline \multirow{2}{*}{$\begin{array}{l}\text { BAP } \\
\left(\mathrm{mgL}^{-1}\right)\end{array}$} & \multirow{2}{*}{$\begin{array}{c}2.4 \mathrm{D}^{2} \\
\left(\mathrm{mgL}^{-1}\right)\end{array}$} & \multirow{2}{*}{$\begin{array}{c}\text { Total number } \\
\text { of embryo }\end{array}$} & \multicolumn{4}{|c|}{ The average number of embryos (\%) at each stage of development } \\
\hline & & & Globular & Heart & Torpedo & Cotyledon \\
\hline 1.0 & 0.0 & 20.2 & $56.4 \pm 5.2 \mathrm{a}$ & $11.9 \pm 2.5 \mathrm{a}$ & $13.8 \pm 2.9 \mathrm{~b}$ & $17.8 \pm 5.6 \mathrm{~d}$ \\
\hline 1.0 & 0.5 & 13.4 & $60.8 \pm 7.9 \mathrm{a}$ & $13.4 \pm 3.9 \mathrm{a}$ & $11.1 \pm 3.2 \mathrm{ab}$ & $14.7 \pm 3.3 \mathrm{~cd}$ \\
\hline 1.0 & 1.0 & 11.0 & $73.6 \pm 4.9 \mathrm{~b}$ & $10.9 \pm 2.9 \mathrm{a}$ & $8.2 \pm 3.0 \mathrm{a}$ & $7.2 \pm 3.8 \mathrm{a}$ \\
\hline 1.0 & 1.5 & 8.9 & $61.2 \pm 6.0 \mathrm{a}$ & $19.1 \pm 4.5 b$ & $10.3 \pm 4.0 \mathrm{ab}$ & $9.4 \pm 5.1 \mathrm{ab}$ \\
\hline 1.0 & 2.0 & 7.7 & $61.8 \pm 7.7 \mathrm{a}$ & $13.1 \pm 6.0 \mathrm{a}$ & $11.9 \pm 4.5 \mathrm{ab}$ & $13.2 \pm 5.4 \mathrm{bc}$ \\
\hline
\end{tabular}

Note: Means \pm SD followed by the same letters on the same column were not significantly different at $(\mathrm{p}<0.05)$ determined by Duncan's Multiple Range Test 
Table 2. Influence of various plant growth regulators (PGRs) on regeneration of somatic embryos

\begin{tabular}{lcccccc}
\hline $\begin{array}{l}\text { BAP } \\
\left(\mathbf{m g L}^{-1}\right)\end{array}$ & $\begin{array}{c}\text { IAA } \\
\left(\mathbf{m g L}^{-1}\right)\end{array}$ & $\begin{array}{c}\text { NAA } \\
\left(\mathbf{m g L}^{-1}\right)\end{array}$ & $\begin{array}{c}\text { Number of leaves } \\
\text { per-plantlet }\end{array}$ & Number of roots & $\begin{array}{c}\text { Plantlet height } \\
(\mathbf{m m})\end{array}$ & Root length (mm) \\
\hline 0.5 & 0.0 & 0.0 & $2.60 \pm 0.52 \mathrm{~b}$ & $1.10 \pm 032 \mathrm{ab}$ & $5.20 \pm 0.17 \mathrm{~d}$ & $0.81 \pm 0.18 \mathrm{a}$ \\
0.0 & 0.5 & 0.0 & $1.90 \pm 0.57 \mathrm{a}$ & $1.20 \pm 0.42 \mathrm{ab}$ & $4.00 \pm 0.35 \mathrm{c}$ & $1.11 \pm 0.23 \mathrm{~b}$ \\
0.0 & 0.0 & 0.5 & $1.60 \pm 0.70 \mathrm{a}$ & $1.80 \pm 0.42 \mathrm{c}$ & $2.98 \pm 0.20 \mathrm{a}$ & $3.13 \pm 0.29 \mathrm{e}$ \\
0.5 & 0.5 & 0.0 & $2.40 \pm 0.52 \mathrm{~b}$ & $0.90 \pm 0.32 \mathrm{a}$ & $5.02 \pm 0.20 \mathrm{~d}$ & $1.32 \pm 0.16 \mathrm{c}$ \\
0.5 & 0.0 & 0.5 & $1.80 \pm 0.42 \mathrm{a}$ & $1.30 \pm 0.48 \mathrm{~b}$ & $3.22 \pm 0.09 \mathrm{~b}$ & $2.12 \pm 0.19 \mathrm{~d}$ \\
\hline
\end{tabular}

Note: Means \pm SD followed by the same letters on the same column were not significantly different at $(\mathrm{p}<0.05)$ determined by Duncan's Multiple Range Test.

\section{Somatic embryo regeneration in media supplemented with different concentration and type of plant growth regulators}

In somatic embryogenesis process, the conversion of embryos into plantlets is an important stage. Previously, Ardiyani (2015) successfully induced embryogenic calli $C$. liberica, however, plantlet regeneration from somatic embryo has not been studied. Table 2 showed the influence of plant growth regulators on cotyledonary embryo development. The cotyledonary embryos measuring about $2 \mathrm{~mm}$ in length were cultured on MS medium given with BAP, IAA, NAA alone or BAP + NAA and BAP + IAA. The results (Table 2) showed that during conversion, all cotyledonary embryos regenerated to form plantlets. MS medium containing $0.5 \mathrm{mgL}^{-1} \mathrm{BAP}$ was found to be the most effective to promote regeneration with 2.6 leaves perplantlet. Also, there was enhanced plantlet height i.e. 5.2 $\mathrm{mm}$, however, there was no significant difference with 0.5 $\mathrm{mgL}^{-1} \mathrm{BAP}+0.5 \mathrm{mgL}^{-1}$ IAA. This information is in line with Ahmed et al. (2013) that the presence of BAP in culture medium promoted embryo conversion into plantlet C. arabica L. Also, Etienne and Bertrand (2003) published similar results in $C$. arabica using relatively high concentration of BAP.

In the present study, among the five tested plant growth regulators, the $0.5 \mathrm{mgL}^{-1} \mathrm{NAA}$ was found to be more effective in increasing the root formation with an average 1.8 roots per-plantlet, and significantly different from other treatments. Here also, enhanced root length was observed, but showed a low number of leaves and plantlet height. In addition, the MS medium given with NAA alone produced highest root number and root length, and is significantly different from other treatments. We reported here successful in vitro plantlets regeneration of $C$. liberica from leaves-derived embryogenic calli via somatic embryogenesis. This regeneration consisted of two steps, which are: somatic embryo development from embryogenic calli and plantlet regeneration from somatic embryos. This invention would be useful for developing protocol of in vitro propagation of liberica coffee via somatic embryogenesis.

\section{ACKNOWLEDGEMENTS}

This study was supported by a grant from Airlangga University, Surabaya, Indonesia as well as the Indonesian Coffee and Cocoa Research Institute, Jember, Indonesia by providing the planting materials.

\section{REFERENCES}

Aga E, Khillare Y. 2017. In vitro multiplication of Coffea arabica L. from leaf explants through indirect somatic embryogenesis. International $\mathbf{J}$ Bot Stud 2 (1): 17-22.

Ahmed W, Feyissa T, Dasasa T. 2013. Somatic embryogenesis of a coffee (Coffea arabica L.) hybrid using leaf explants. J Hortic Sci Biotechnol 88 (4) 469-475. DOI: 10.1080/14620316.2013.11512993

Ardiyani F. 2015. Morphological characterization and identification of Coffea liberica callus of somatic embryogenesis propagation. Pelita $\begin{array}{llll}\text { Perkebunan } & 31 & (2): & 81-89 .\end{array}$ 10.22302/iccri.jur.pelitaperkebunan.v31i2.168

Arnold S.V, Izabela. S, Peter, B, Julia. D, Lada. F. 2002. Developmental pathways of somatic embryogenesis. Plant Cell Tiss Organ Cult 69: 233-249. DOI: 10.1023/A:1015673200621

Campos NA, Panis B, Carpentier SC. 2017. Evolution of biotechnology and the integration of omics technologies offer grea0t opportunities. Front Plants Sci 21 (8): 1-12. DOI: 10.3389/fpls.2017.0146.

Chithra M, Martin KP, Sunandakumari C, Madhusoodanan PV. 2005. Somatic embryogenesis, encapsulation, and plant regeneration of Rotula aquatica Lour., a rare rhoeophytic woody medicinal plant. In Vitro Cell Dev Biol Plant 41: 28-31. DOI: 10.1079/IVP2004598.

Davis AP, Govaerts R, Bridson DM, Stoffelen P. 2006. An annotated taxonomic conspectus of the genus Coffea (Rubiaceae). Bot J Linn Soc 152 (4): 465-512.

Duncan DB. 1955. Multiple range and multiple F tests. Biometrics 11 (1): $1-42$.

Etienne H, Anthony F, Dussert S, Fernandez D, Lashermes P, Bertrand B. 2002. Biotechnological applications for the improvement of Coffee (Coffea arabica L.). In Vitro Cell Dev Biol Plant 38: 129-138. DOI: 10.1079/IVP2001273.

Etienne H, Breton D, Breitler JC, Bertrand B, Déchamp E, Awada R, Marraccini P, Léran S, Alpizar E, Campa C, Caurtel P, Georget F, Paul DJ. 2018. Coffee somatic embryogenesis: How did research, experience gained and innovations promote the commercial propagation of elite clones from the two cultivated species? Review. Front Plant Sci 12: 1-21. DOI: 10.3389/fpls.2018.01630.

Etienne H, Bertrand B. 2003. Somaclonal variation in Coffea arabica: Effects of genotype and embryogenic cell suspension age on frequency and phenotype of variants. Tree Physiol 23 (6): 419-26. DOI: 10.1093/treephys/23.6.419. 
Etienne H, Dechamp E, Barry-Etienne D, Bertrand B. 2006. Bioreactors in coffee micropropagation. Brazilian J Plant Physiol 18: 45-54. DOI: 10.1590/S1677-04202006000100005.

Fu X, Qi L, Hulke B, Seiler G, Chien JC. 2017. Somatic embryogenesis from corolla tubes of interspecific amphiploids between cultivated sunflower (Helianthus annuus L.) and its wild species. Helia 40 (66): 1-19. DOI 10.1515/helia-2017-0006.

Gatica-arias AM, Arrieta-Espinoza G, Esquivel AMS. 2008. Plant regeneration via indirect somatic embryogenesis and optimization of genetic transformation in Coffea arabica L. cvs. Caturra and Catuaí. Electr J Biotechnol 11 (1): 1-12. DOI: 10.2225/vol11-issue1-fulltext9.

Giridhar P, Kumar V, Indu EP, Ravishankar GA, Chandrasekar A. 2004 Thidiazuron induced somatic embryogenesis in Coffea arabica L. and Coffea canephora $\mathrm{P}$ ex Fr. Acta Bot Croat 63 (1): 25-33.

Herrera AA, Gonzalez AK, Moo RC, Figueroa FRQ, Vargas VML, Zapata LCR, D'Hondt CB, Solı's VMS, Castano E. 2008. Expression of WUSCHEL in Coffea canephora causes ectopic morphogenesis and increases somatic embryogenesis. Plant Cell Tiss Organ Cult 94 171-180. DOI. 10.1007/s11240-008-9401-1.

Ibrahim MSD, Hartati RSS, Rubiyo, Purwito A, Sudarsono. 2015. The induction of primary and secondary somatic embryogenesis for Arabica coffee propagation. J Trop Crop Sci 2 (3): 6-13. DOI: 10.29244/jtcs.2.3.6-13

Jeminez VM, Guevera E, Herrera J, Bangreth F. 2001. Endogenous hormone levels in habituated nucellar Citrus callus during the initial stages of regeneration. Plant Cell Rep 20: 92-100. DOI $10.1007 / \mathrm{s} 002990000280$.

Jimenez VM. 2005. Involvement of plant hormones and plant growth regulators on in vitro somatic embryogenesis. Plant Growth Regul 47 91-110. DOI:10.1007/s10725-005-3478-x.

Kahia J, Kirika M, Lubabali H, Mantel S. 2016. High-frequency direct somatic embryogenesis and plantlet regeneration from leaves derived from in vitro-germinated seedlings of a Coffea arabica hybrid cultivar. HortScience 51 (9):1148-1152. DOI 10.21273/HORTSCI10771-16.

Konar S, Karmakar J, Ray A, Adhikari S, Bandyopadhyay TK. 2018. Regeneration of plantlets through somatic embryogenesis from rootderived calli of Hibiscus sabdariffa L. (Roselle) and assessment of genetic stability by flow cytometry and ISSR analysis. PLoS ONE 13 (8): e0202324. DOI: 10.1371/journal. pone.0202324.

Mira MM, Wally OSD, Elhiti M, El-Shanshory A, Reddy DS, Hill RD, Stasolla C. 2016. Jasmonic acid is a downstream component in the modulation of somatic embryogenesis by Arabidopsis Class 2 phytoglobin. J Exp Bot 67: 2231-2246. DOI:10.1093/jxb/erw022.
Murashige T, Skoog F. 1962. A revised medium for rapid growth and bioassays with tobacco tissue cultures. Physiol Plant 15: 473-497. DOI: 10.1111/j.1399-3054.1962.tb08052.x

N'Diaye A, Poncet V, Louarn J, Hamon S, Noirot M. 2005. Genetic differentiation between Coffea liberica var. liberica and C. liberica var. dewevrei and comparison with $C$. canephora. Plant Syst Evol 253: 95-104. DOI: 10.1007/s00606-005-0300-1.

Nic-Can GI, Galaz-Ávalos RM, De-la-Peña C, Alcazar-Magaña A, Wrobel K, Loyola-Vargas VM. 2015. Somatic embryogenesis: Identified factors that lead to embryogenic repression. A case of species of the same genus. PLoS ONE 10 (6): e0126414. DOI: 10.1371/journal.pone.0126414.

Pádua MS, Santos RS, Labory CRG, Stein VC, Mendonça EG, Alves E, Paiva, LV. 2018. Histodifferentiation of oil palm somatic embryo development at low auxin concentration. Protoplasma 255:285-295. DOI: 10.1007/s00709-017-1143-7.

Santana-Buzzy N, Rojas-Herrera R, Galaz-Ávalos RM, Ku-Cauich JR, Mijan gos-Cortés J, Gutiérrez-Pacheco LC, Canto A, Quiroz-Figueroa F, Loyola-Vargas VM. 2007. Advances in coffee tissue culture and its practical applications. In Vitro Cell Dev Biol Plant 43: 507-520. DOI: 10.1007/s11627-007-9074-1.

Venkataiah P, Bhanuprakash P, Kalyan SS, Subhash K. 2016. Somatic embryogenesis and plant regeneration of Capsicum baccatum L. J Genetic Eng Biotechnol 14: 55-60. DOI: 10.1016/j.jgeb.2016.02.001.

Verma SK, Das AK, Gantait S, Gurel S, Gurell E. 2018. Influence of auxin and its polar transport inhibitor on the development of somatic embryos in Digitalis trojana. Biotech 8: 99. DOI: 10.1007/s13205-018-1119-0.

Vondráková Z, Krajňáková J, Fischerová L, Vágner M, Eliášová K. 2016. Physiology and role of plant growth regulators in somatic embryogenesis. In Vegetative Propagation of Forest Trees; Park YS, Bonga JM, Moon HK (eds.). National Institute of Forest Science, Seoul, Korea.

Vondráková Z, Eliášová K, Fischerová L, Vágner M. 2011. The role of auxins in somatic embryogenesis of Abies alba. Central Eur J Biol 6 (4) :587-596. DOI: 10.2478/s11535-011-0035-7.

Yang, X, Zhang X. 2010. Regulation of somatic embryogenesis in higher plants. Crit Rev Plant Sci 29: 36-57. DOI: 10.1080/07352680903436291.

Zou S, Yao X, Zhong C, Li D, Wang Z, Huang H. 2019. Recurrent somatic embryogenesis and development of somatic embryos in Akebia trifoliata (Thunb.) Koidz (Lardizabalaceae). Plant Cell Tiss Organ Cult 1-12. DOI: 10.1007/s11240-019-01686-4. 